\title{
Dampak Konseling Adiksi terhadap Klien Pasca Rehabilitasi Narkoba di Yayasan Pradita Madani Cempaka Kec. Kedawung Kab. Cirebon
}

\author{
Herman Beni ${ }^{1}$, Dini Aryanie ${ }^{2}$ \\ ${ }^{1}$ Program Studi Bimbingan Konseling Islam, Fakultas Ushuluddin Adab dan Dakwah, \\ IAIN Syekh Nurjati Cirebon \\ Email Penulis ${ }^{1}$ : hermanbeni0430@gmail.com \\ ${ }^{2}$ Program Studi Bimbingan Konseling Islam, Fakultas Ushuluddin Adab dan Dakwah, \\ IAIN Syekh Nurjati Cirebon \\ Email Penulis ${ }^{2}$ : aryanie.dini@gmail.com
}

\begin{abstract}
Abstrak
Penelitian ini di latar belakangi oleh klien pasca rehabilitasi yang mengalami permasalahan mengenai kambuh (Relaps) setelah mengikuti program rehabilitasi narkoba. Dimana klien tidak bisa mengontrol untuk tidak memakai narkoba. Selain itu agar klien pasca rehabilitasi narkoba agar bisa mengontol dan mengawas diri agar tidak kambuh (relaps). Adapun tujuan dari penelitian ini adalah untuk mengetahui pelaksanaan konseling adiksi, mengetahui dampak konseling adiksi terhadap klien pasca rehabilitasi, mengetahui cara mencegah kambuh (relaps) klien pasca rehabilitasi di Yayasan Pradita Madani Cempaka. Metode yang digunakan dalam penelitian ini adalah penelitian deskriptif kualitatif, teknik pengumpulan datanya menggunakan teknik wawancara, observasi, dan dokumentasi. Analisis data menggunakan model Miles dan Huberman yaitu dengan reduksi data, penyajian data dan verification. Hasil penelitian ini: pertama, pelaksanaan konseling adiksi ada jangka pendek, jangka menegah, dan jangka panjang dan metode konseling adiksi FGD, FSG dan pemberian materi mengenai kambuh. Kedua, dampak konseling Adiksi yang di rasakan oleh klien pasca rehabilitasi narkoba untuk mencegah kambuh (relaps) sendiri berdampak positif, dengan wujud sikap optimis dan bersikap positif. Ketiga, cara mencegah kambuh (relaps) pada klien pasca rehabilitasi narkoba setelah mengikuti layanan konseling adiksi dengan subjek F, H, A, ASR. niat, menjauhkan diri dari lingkungan negatif, memilah teman yang baik, mempunyai kegiatan, dukungan keluarga dan berserah diri kepada Allah SWT.
\end{abstract}

Kata Kunci: Konseling Adiksi; Kambuh (Relaps); Klien Pasca Rehabilitasi Narkoba. 


\section{PENDAHULUAN}

Arus globalisasi yang semakin berkembang saat ini telah menyebabkan arus komunikasi dan transportasi antar benua maupun antar negara tidak mengalami hambatan. Arus globalisasi memberikan dampak negatif bagi individu, masyarakat, wilayah maupun negara. Begitu juga dengan peredaran dan perdagangan NAPZA antar negara. Penyalahgunaan narkoba di Indonesia sudah mencapai tahap yang sangat mengkhawatirkan. tidak hanya kalangan remaja di perkotaan, bahkan sudah menjalar ke kalangan anak-anak di pedesaan.

Al-Maidah ayat 90:

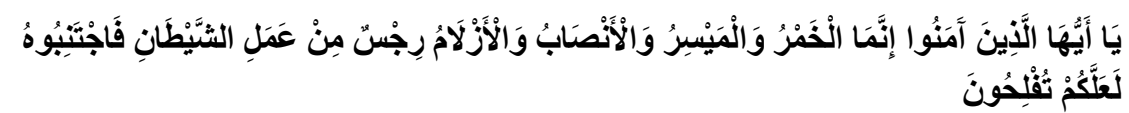

Artinya: "Hai orang-orang yang beriman, sesungguhnya khamar, judi, berkorban untuk berhala, mengundi nasib dengan panah adalah perbuatan keji termasuk perbuatan syetan. Maka jauhilah perbuatan-perbuatan itu agar kamu mendapat keberuntungan.”(Q.S.Al-Maidah:90) (Sayyid Sabiq, 2009:184).

Ayat 90 surah al-maidah merupakan dalil al-Qur'an tentang keharaman narkotika, sebagaimana Sayyid Sabiq mengqiyaskannya kepada khamer. Menurut Quraish Sihab dalam tafsir al-Misbah, bahwa sifat keharaman khamer baik banyak maupun sedikit tetap haram, sedikitnya khamer mengundang keinginan untuk mencoba lebih banyak hingga benar-benar merasa nikmat bagi peminumnya. Perbuatan yang demikian menurut beliau termasuk perbuatan yang bertujuan membinasakan diri (Quraish Shihab, 2004: 231).

Melihat situasi saat observasi, peneliti menemukan permasalahan bahwa perlunya sikap yang kuat terhadap diri oleh klien pascka rehabilitasi agar proses yang telah di lalui tidak terbuang sia-sia. Dalam usaha menyelesaikannya, peneliti memberi kesimpulan sementara dari fenomena yang terjadi di Yayasan pradita Madani Cempaka ini. Pertama Adanya pengaruh dari lingkungan sekitar yang tidak mendukung untuk mantan pengguna berhenti memakainya lagi. Kedua penerapan proses rehabilitasi menggunakan metode konseling adiksi dalam mengatasi relaps bagi klien pasca rehabilitasi. Ketiga banyaknya pemakaian narkotika dan obat-obatan terlarang sehingga mudah mempengaruhi bagi klien pasca rehabilitasi dalam pemulihan untuk memakainya kembali/relaps.

Melihat permasalahan yang telah diuraikan, peneliti tertarik untuk melakukan penelitian tentang bagaimana " dampak konseling adiksi terhadap klien pasca rehabilitasi untuk mencegah Relaps di Yayasan Pradita Madani Cempaka di Kecamatan Kedawung, Kabupaten Cirebon". Menurut Cavanagh (1982) yang di kutip oleh Susanto (2018:6) Konseling adalah kegiatan yang di lakukan oleh konselor untuk memperoleh suatu hubungan antara pemberi bantuan yang terlatih dengan seorang yang mencari bantuan, bantuan yang diberikan berupa keterampilan dan penciptaan suasana yang membantu orang lain agar dapat belajar berhubungan dengan dirinya sendiri dan orang lain melalui cara-cara yang lebih tumbuh dan produktif. 
Konseling adalah upaya membantu individu melalui proses interaksi yang bersifat pribadi antara konselor dan konseli agar konseli mampu memahami diri dan lingkungannya, mampu membuat keputusan dan menentukan tujuan berdasarkan nilai yang di yakini sehingga konseli merasa bahagia dan efektif perilakunya. (Nurihsan, 2006:10). Konseling merupakan salah satu teknik dalam bimbingan, tetapi merupakan teknik inti atau teknik kunci. Hal ini dikarenakan konseling dapat memberikan perubahan yang mendasar, yaitu mengubah sikap. Sikap mendasari perbuatan, pemikiran, pandangan dan perasaan, dan lain-lain (Hikmawati, 2010:2).

Adiksi adalah suatu keadaan ketika seseorang yang bila menggurangi atau menghentikan penggunakan zat psikoaktif tertentu secara teratur, sering, dan cukup banyak, ia akan mengalami sejumlah gejala fisik maupun mental, sesuai dengan jenis zat yang biasa digunakannya. Adiksi dimaksudkan sebagai ketergantungan fisik saja (Joewana, 2005:23). Salah satu jalan yang ditempuh pengguna narkoba agar tidak kecanduan lagi yaitu dengan rehabilitasi. Rehabilitasi adalah suatu proses pengobatan untuk membebaskan pecandu dari ketergantungan, dan masa menjalani rehabilitasi tersebut diperhitungkan sebagai menjalani hukuman. Rehabilitasi juga merupakan bentuk perlindungan sosial yang mengintegrasikan pecandu narkoba ke dalam tertib sosial agar dia tidak lagi melakukan penyalahgunaan narkotika (Zubaidah, 2011:35).

Bukan tidak mungkin pengguna narkoba yang sudah melakukan rehabilitasi kembali menggunakan narkoba atau kambuh (relaps). Menurut Setyawati (2015:84) Relaps yaitu peristiwa mantan pecandu yang telah beberapa lama tidak memakai narkoba kembali memakai narkoba dan terus mengonsumsinya. Adapun sebelum penelitian ini dilaksanakan telah ada penelitian terdahulu yang relevan, yaitu penelitian yang dilakukan oleh Endaria $S$ Munthe (2017) Hasil penelitian ini menjelaskan bahwa faktor eksternal dari penyebab relaps ternyata lebih kuat pengaruhnya dari pada faktor internal penyebab relaps. Penelitian ini menggunakan negative feeling pada faktor internal dan faktor ekonomi, sedangkan faktor eksternal terdiri dari social pressuredan lingkungan. Perbedaan penelitian ini dengan yang akan dilakukan oleh peneliti adalah dari segi tempat penelitian, subjek penelitian, dan variabel penelitian.

Penelitian lainnya yaitu yang dilakukan Siti Rahmawati (2010), hasil penelitian ini menjelaskan bahwa mantan pengguna NAPZA yang kembali kambuh (relaps) adanya konflik batin yang dirasakan partisipan yang membuat mereka sulit berpikir positif untuk menyelesaikan masalah dengan benar sehingga membuat mereka memilih melarikan diri (respon flight) dan menghindar dari masalah yang di hadapi dengan kembali menggunakan NAPZA agar kembali merasa tenang, nyaman dan bebas dari masalah yang dihadapi. Penelitian ini menggunakan fenomenologi untuk mengetahui makna kata relaps bagi seorang mantan atau pengguna NAPZA dan lebih di arahkan untuk memahami dan mengeksplorasi lebih dalam tentang proses terjadinya relaps pada mantan pengguna NAPZA. Perbedaan penelitian ini dengan yang akan dilakukan oleh peneliti adalah variabel penelitian. 
Selain itu pula ada penelitian yang dilakukan oleh Indra Dwi Purnomo dan George Hardjanto (2016), hasil penelitian ini menjelaskan terapi tidak menunjukan tidak ada perbedaan secara signifikan antara kelompok eksperimen dengan kelompok kontrol. Penelitian ini menggunakan frekuensi (kecenderungan) relaps antara kelompok kontrol eksperimen setelah di berikan terapi dengan pendekatan konsep Congnitive-Behavioral Therapy (CBT). Pengguna narkoba yang telah selesai mengikuti proses rehabilitasi akan tetapi belum pernah mengkuti terapi atau belum mendapatkan terapi yang berhubungan dengan relaps. Perbedaan penelitian ini dengan yang akan dilakukan oleh peneliti adalah dari segi pendekatan konsep penelitian, subjek penelitian, dan variabel penelitian. Sedangkan persamaan penelitian terdahulu dengan yang akan peneliti teliti adalah samasama meneliti tentang mencegah relaps.

Tujuan dari penelitian ini yaitu: (1) untuk mengetahui pelaksanaan konseling adiksi terhadap klien pasca rehabilitasi untuk mencegah Relaps di Yayasan Pradita Madani Cempaka; (2) Mengetahui dampak konseling adiksi terhadap klien pasca rehabilitasi untuk mencegah Relaps di Yayasan Pradita Madani Cempaka; dan (3) Mengetahui cara mencegah kambuh (relaps) klien pasca rehabilitasi di Yayasan Pradita Madani Cempaka.

\section{METODE PENELITIAN}

Jenis penelitian ini adalah penelitian kualitatif. Menurut Denzin dan Licoln (2009), kata kualitatif menyiratkan penekanan pada proses dan makna yang tidak dikaji secara ketat atau belum diukur dari sisi kuantitas, jumlah, intensitas, atau frekuensinya. Pendekatan kualitatif adalah suatu proses penelitian dan pemahaman yang berdasarkan pada metodologi yang menyelidiki suatu fenomena sosial dan masalah manusia. Pada pendekatan ini, peneliti menekankan sifat realitas yang terbangun secara sosial, hubungan erat antara peneliti dan subjek yang diteliti (Noor, 2013: 33-34).

Teknik pendekatan yang peneliti gunakan adalah dengan purposive sampling, didasarkan pada suatu pertimbangan tertentu yang dibuat oleh peneliti sendiri, berdasarkan ciri atau sifat-sifat populasi yang sudah diketahui sebelumnya. Pelaksanaan pengambilan sampel yang menggunakan teknik ini, mula-mula peneliti harus mengidentifikasi semua karakteristik populasi, baik mengadakan studi pendahuluan terlebih dahulu, maupun dengan cara lain dalam mempelajari berbagai hal yang berhubungan dengan populasi. Setelah itu barulah peneliti menetapkan berdasarkan pertimbangannya, sebagian dari anggota populasi menjadi sampel penelitian.

Sumber data dalam penelitian ini adalah berupa data primer dan data sekunder. Data primer merupakan data yang diperoleh secara langsung dari sumbernya dan diolah peneliti dan lembaga untuk bersangkutan untuk dimanfaatkan. Ada dua cara dalam memperoleh data primer melalui observasi dan wawancara. Data sekunder adalah data yang diperoleh secara tidak langsung atau melalui media perantara yang dihasilkan oleh pihak lain seperti penelitian terdahulu yang berupa buku seri Bahaya Narkoba Penyalahgunaan Narkoba jilid 3 dan Penyembuhan Korban Narkoba Melalui Terapi dan Rehabilitasi Terpadu, skripsi, jurnal, artikel maupun majalah yang berkaitan dengan penelitian ini. 
Observasi, pada teknik ini digunakan oleh peneliti untuk mengamati bagaimana proses konseling adiksi yang dilaksanakan oleh pekerja sosial atau konselor di Yayasan Pradita Madani Cempaka di komplek Taman Kapuk Permai Kecamatan Kedawung Kabupaten Cirebon secara lebih nyata dan mendalam. Kemudian, wawancara dilakukan untuk memperoleh data yang relevan, yang mana peneliti melakukan wawancara atau interview kepada pekerja sosial atau konselor dan klien pasca rehabilitasi remaja di Yayasan Pradita Madani Cempaka di komplek Taman Kapuk Permai Kecamatan Kedawung Kabupaten Cirebon. Adapun untuk dokumentasi, sebagian besar datanya tersedia dalam bentuk surat, catatan harian, cendera mata, laporan, artefak, dan foto. Sifat utama data ini tak terbatas pada ruang dan waktu sehingga memberi peluang kepada peneliti untuk mengetahui hal-hal yang pernah terjadi diwaktu silam. Secara detail, bahan. Pada penelitian ini peneliti mengumpulkan data terkait subjek penelitian dengan teknik dokumentasi baik berupa arsip, surat, foto.

Untuk menganalisa data yang telah diperoleh, peneliti menggunakan model Miles dan Huberman yaitu data reduction (reduksi data), data display (penyajian data), dan conclusion drawing/verivication (Sugiyono, 2016:337-345). Mereduksi data berarti merangkum, memilih hal-hal yang pokok, memfokuskan pada hal-hal yang penting, dicari tema dan polanya dan membuang yang tidak perlu. Langkah selanjutnya adalah mendisplay data atau menyajikan data. Dalam penelitian kualitatif, penyajian data dapat dilakukan dalam bentuk uraian singkat, bagan, hubungan antar kategori, flowchart, dan sejenisnya. Pada penelitian ini, setelah tahap penyajian data selesai maka akan dilakukan penarikan kesimpulan dari data yang diperoleh di lapangan setelah dianalisis dengan teori. Penelitian dalam hasil ketiga proses mengolah data ini akan direfleksikan dengan menggunakan teori konseling adiksi.

\section{HASIL DAN PEMBAHASAN}

\section{Proses Pelaksanaan Konseling Adiksi di Yayasan Pradita Madani Cempaka}

Berdasarkan hasil wawancara peneliti dan konselor/peksos diperoleh bahwa proses pelaksanaan konseling adiksi sendiri mempunyai beberapa tahapan yang harus di lalui diantaranya yaitu proses skrining dengan menggunakan instrumen tertentu. Tujuan di lakukan skrining ini hanya untuk mendapatkan informasi adakah suatu faktor resiko atau masalah terkait dengan penggunaan narkotika sendiri dan wawancara mengenai riwayat penggunaan narkotika. Setelah di lakukan skrining selanjutnya proses identifikasi awal ini mengidentifikasi masalah berdasarkan laporan awal mengenai penggunaan zat klien dan di lanjutkan dengan tes urine yang di lakukan 1 bulan sekali untuk memastikan bahwa klien tersebut sudah tidak memakainya lagi. Selanjutnya di lakukan assesmen awal dapat di selesaikan dalam dua kali pertemuan.

Pada beberapa pasien dengan kondisi fisik baik dan sikap yang kooperatif, assesmen juga bahkan dapat di selesaikan dalam sekali pertemuan. Selanjutnya rencana pemecahan masalah yaitu sidang kasus maksud di sini ketika klien terkena pasal tentang rehabilitasi maka iya wajib mengikuti proses rehabilitasi sosial dan yang terakhir pelaksanaan 
pemecahan masalah sendiri tergantung pada klien sendiri apa yang di butuhkan di lihat dari assesmen awal untuk menyelesaikan permasalahannya. Setelah mengetahui penyelesaian masalahnya konselor berdiskusi terlebih dahulu sebelum di serahkan kepada klien narkotika untuk menyetujui kontrak pelaksanaan pemecahan masalah.

Ada beberapa layanan yang di berikan oleh Yayasan Pradita Madani Cempaka berdasarkan wawancara peneliti dengan konselor atau peksos, Menurut pak Maha:

"layanan konseling adiksi sendiri ada jangka pendek, jangka menengah dan jangka panjang. Jangka pendek berupa rawat jalan, jangka menengah berupa proses pemulihan klien, dan yang ketiga adalah jangka panjang yang berupa di berikan keterampilan agar setelah selesai mereka mempunyai keahlian khusus dan di berikan penambahan modal untuk melanjutkan hidupnya, dan terakhir ada layanan Home Visit kunjungan rumah ke klien rehabilitasi" (wawancara hari Rabu, 24 April 2019).

Dari hasil observasi dan wawancara peneliti pada kegiatan layanan konseling adiksi di Yayasan Pradita Madani Cempaka yaitu dengan menggunakan metode FGD (Fokus Grup Diskusi) yaitu diskusi terarah mengenai penangganan proses kekambuhan (relaps) diskusi ini di lakukan oleh perkumpulan mantan pengguna napza tujuan di adakan FGD ini untuk memacu klien pasca rehabilitasi narkoba yang lain agar tergerak untuk sembuh dari penggunaan narkotika selain itu saling memotivasi dan memberikan dukungan antara individu satu dengan yang lainnya untuk sembuh dan menjauhkan dari narkoba. dan FSG (Family Support Grup) yaitu memberikan dukungan kepada keluarga untuk membantu dalam proses pemulihan agar tidak kambuh (relaps) kembali dan komitmen keluarga untuk selalu mendukung dan menerimanya kembali. Dari metode-metode konseling adiksi tersebut memberikan perubahan pada proses kambuh (relaps) klien pasca rehabilitasi yang dibina di Yayasan Pradita Madani Cempaka ke arah yang lebih baik untuk mencegah terjadinya kambuh (relaps).

\section{Dampak Konseling Adiksi Terhadap Klien Pasca Rehabilitasi Narkoba untuk Mencegah Kambuh (Relaps) di Yayasan Pradita Madani Cempaka}

Subjek dalam penelitian ini, yaitu subjek F, subjek H, subjek A, dan subjek ASR. Dari hasil wawancara peneliti dengan klien pasca rehabilitasi nakoba di Yayasan Pradita Madani Cempaka yaitu Subjek F, H, A, dan ASR. Perubahan secara internal yang dirasakan oleh klien pasca rehabilitasi yaitu:

1. Subjek F

Ditemukan bahwa perubahan secara internal setelah mengikuti konseling adiksi yaitu $\mathrm{F}$ lebih tau mengenai dampak yang di timbulkan dari pemakaian narkoba secara terus menerus. Sebelumnya $F$ sudah mengetahui tentang bahaya yang di timbulkan, seiring berjalannya waktu dan pengalaman-pengalaman yang $\mathrm{F}$ dapatkan, serta mengikuti kegiatan konseling adiksi dan menambah motivasi untuk sembuh dan tidak terjerumus kembali untuk menggunkannya lagi. F mengungkapkan ada perubahan dalam dirinya untuk tidak memakainya lagi, yaitu dengan berhenti menggunakannya lagi yang sudah di sampaikan dari materi-materi pada kegiatan konseling adiksi. 


\section{Subjek H}

Dari hasil wawancara peneliti dengan H pada hari Rabu, 24 April 2019. Ditemukan bahwa perubahan secara internal setelah mengikuti konseling adiksi yaitu $\mathrm{H}$ lebih berpikir positif untuk mengambil tindakan tidak dengan nafsunya. Sebelumnya $\mathrm{H}$ sudah tau mana yang baik dan buruk akan tetapi emosional yang tidak terkontrol, seiring berjalannya waktu dan pengalaman-pengalaman yang $\mathrm{H}$ dapatkan, serta mengikuti kegiatan konseling adiksi dan menambah motivasi untuk sembuh dan tidak terjerumus kembali untuk menggunakannya lagi. $\mathrm{H}$ mengungkapkan ada perubahan dalam dirinya untuk tidak memakainya lagi, yaitu dengan berhenti menggunakannya lagi yang sudah di sampaikan dari materi-materi pada kegiatan konseling adiksi.

3. Subjek A

Dari hasil wawancara peneliti dengan A pada hari Jum'at, 26 April 2019. Ditemukan bahwa perubahan secara internal setelah mengikuti konseling adiksi yaitu A lebih merasa plog dan lega. Sebelumnya A terbebani dengan permasalahan yang di milikinya, seiring berjalannya waktu dan pengalaman-pengalaman yang A dapatkan, serta mengikuti kegiatan konseling adiksi dan menambah motivasi untuk sembuh dan tidak terjerumus kembali untuk menggunakannya lagi. A mengungkapkan ada perubahan dalam dirinya untuk tidak memakainya lagi, yaitu dengan berhenti menggunakannya lagi yang sudah di sampaikan dari materi-materi pada kegiatan konseling adiksi.

4. Subjek ASR

Dari hasil wawancara peneliti dengan A pada hari Rabu 01 Mei 2019. Ditemukan bahwa perubahan secara internal setelah mengikuti konseling adiksi yaitu ASR lebih ada penguatan untuk sembuh. Sebelumnya ASR tidak ada penguatan pada dirinya untuk sembuh, seiring berjalannya waktu dan pengalaman-pengalaman yang ASR dapatkan, serta mengikuti kegiatan konseling adiksi dan menambah motivasi untuk sembuh dan tidak terjerumus kembali untuk menggunakannya lagi. ASR mengungkapkan ada perubahan dalam dirinya untuk tidak memakainya lagi, yaitu dengan berhenti menggunakannya lagi yang sudah di sampaikan dari materi-materi pada kegiatan konseling adiksi.

Didapati perubahan klasifikasi secara internal yang positif dari subjek F, H, A, dan ASR tersebut yaitu:

a. Antusias mengikuti kegiatan layanan konseling adiksi.

b. Lebih berpikir positif.

c. Terbantu dalam pemecahan permasalahan.

d. Bersikap optimis untuk sembuh.

Adapun didapati perubahan klien pasca rehabilitasi yang negatif tersebut yaitu, tidak setiap pertemuan melakukan proses konseling. 
Dari hasil wawancara peneliti dengan klien pasca rehabilitasi narkoba yang di bina di Yayasan Pradita Madani Cempaka setelah mengikuti kegiatan konseling adiksi, di dapat data mengenai perubahan secara eksternal pada klien pasca rehabilitasi narkoba, yaitu:

1. Subjek F

Dari hasil wawancara peneliti dengan $\mathrm{F}$ dapat di lihat pada perubahan eksternalnya yaitu $\mathrm{F}$ lebih mendekatkan diri pada orang tua dan menjauhkan diri dari lingkungan dan teman yang negatif. Sebelumnya F orangnya tertutup kepada orang tua dan bergaul dengan teman yang memakai narkoba, setelah mengikuti konseling adiksi $\mathrm{F}$ sudah lebih terbuka untuk curhat dengan orang tuanya. Dalam hubungan lingkungan sosialnya $\mathrm{F}$ merasakan baik-baik saja dan tidak ada permasalahan, karena $\mathrm{F}$ sudah bisa membangun pertemanan yang positif. Dan untuk permasalahan mencegah kekambuhan pada dirinya dengan berusaha menjauhkan dirinya dari hal-hal yang membuat iya memakai kembali.

2. Subjek H

Dari hasil wawancara dengan peneliti dengan $H$ dilihat pada perubahan eksternalnya setelah mengikuti kegiatan layanan konseling adiksi yaitu $\mathrm{H}$ dalam menyelesaikan permasalahannya dengan kepala dingin dan di omongin baik-baik. Dan cara menghindarin narkoba dengan cara menjauhkan diri dari teman atau pergaulan yang tidak baik cara meminimalisirnya juga dengan cara dengerin musik.

3. Subjek A

Dari hasil wawancara peneliti dengan A dapat dilihat pada perubahan eksternalnya setelah mengikuti kegiatan layanan konseling adiksi yaitu dalam hubungan dengan orang tuanya baik dan lebih senang dengan pribadi yang sekarang. A lebih meningkatkan kualitas dirinya dengan cara mendekatkan diri dengan allah dan berpasrah dengan cara niat dan tekat yang kuat untuk sembuh dari narkoba. Dan cara penyelesaian permasalahannya dengan di bicarakan dengan baik-baik antara dirinya dan orang bersangkutan.

4. Subjek ASR

Dari hasil wawancara peneliti dengan ASR dapat dilihat pada perubahan eksternalnya setelah mengikuti kegiatan layanan konseling adiksi yaitu dalam hubungan dengan keluarganya baik dan lebih dapat mengontol emosi dan tidak tempramen. ASR lebih meningkatkan kualitas dirinya dengan cara mendekatkan diri dengan allah, menjauhkan diri dari pergaulan negatif, dan fokus terhadap keluarga untuk sembuh dari narkoba, serta cara penyelesaian permasalahannya dengan kekeluargaan.

Didapati perubahan klasifikasi secara eksternal pada klien pasca rehabilitasi yang lebih bersifat positif pada subjek F,H,A, dan ASR yaitu:

a. Terbuka terhadap orang tua.

b. Hubungan dengan orang tua, lingkungan sekitar, dan teman baik.

c. Dapat mengontol emosi. 
Adapun didapati perubahan klien pasca rehabilitasi yang negatif tersebut yaitu, kurang baik hubungannya dengan keluarga, lingkungan, dan teman.

Pedoman wawancara yang dilakukan peneliti mengacu pada kajian teori menurut Marlatt dan Gordon (Larimer, ddk,1999) mengemukakan beberapa faktor yang dapat memicu terjadinya relaps pada pecandu narkoba. Terdapat dua kategori, yakni faktor yang berasal dari dalam diri individu (internal) maupun dari lingkungan (eksternal). Faktor internal memicu terjadinya relaps diantaranya yaitu: efikasi diri, motivasi, craving, coping, emotional states, dan outcome expetancies. Sedangkan faktor eksternal yang dapat memicu terjadiya relaps yaitu adanya situasi sosial yang menekan dan munculnya konflik interpersonal.

Berdasarkan teori mengenai kambuh (relaps) pada dimensi efikasi diri atau kemampuan diri dan hasil wawancara peneliti dengan subjek F, H, A, dan ASR. Didapati pada dimensi ini F, H, A, dan ASR. Dapat mengenali kemampuan dirinya untuk sembuh dari narkoba, seperti dapat menjauhkan dirinya dengan hal-hal yang negatif dan mencoba untuk mendekatkan dirinya dengan hal-hal yang bersifat positif bagi mereka. F mengatakan usaha yang dilakukannya yaitu dengan niat dan menjauhkan dirinya dari hal yang negatif. $\mathrm{H}$ mengatakan dengan cara menambah wawasannya mengenai penyuluhan narkoba dan mempunyai kesibukan agar terhindar dari narkoba. A mengatakan segala hal positif bagi dirinya untuk berhenti dari narkoba akan di lakukan dan lebih mendekatkan diri dengan cara beribadah. ASR mengatakan yakin terhadap diri sendiri untuk sembuh lalu dukungan keluarga sangat penting bagi kesembuhan dan mendekatkan diri dengan allah SWT.

Berdasarkan teori mengenai kambuh (relaps) pada dimensi motivasi dan hasil wawancara peneliti dengan subjek F, H, A, dan ASR. Didapati pada dimensi ini F, H, A, dan ASR. Dapat mengenali tentang motivasi yang ada pada dirinya terutama keluarganya sendiri. F lebih ke keluarganya terutama orang tua dan anaknya. $\mathrm{H}$ lebih kekeluarganya dan menyayangi tubuhnya. A lebih ke kedua orang tuanya dan ASR lebih ke anaknya yang membutuhkan sesosok ayahnya.

Berdasarkan teori mengenai kambuh (relaps) pada dimensi kecanduan (craving) dan hasil wawancara peneliti dengan subjek F, H, A, dan ASR. Didapat pada dimensi ini subjek F, H, A, dan ASR. Dapat mengatasi kecanduan untuk memakai narkoba dengan cara mengisi berbagai kegiatan dan memilih lingkungan yang baik. Subjek F bentuknya dengan penyangkalan pada diri untuk tidak memakai. Subjek H memperbanyak kegiatan agar sibuk memikirkan kerja. Subjek A dengan mendekatkan diri kepada allah. Dan subjek ASR dengan memilih pergaulan dan teman yang baik.

Adapun berdasarkan teori kambuh (relaps) pada dimensi penanganan (coping) dan hasil wawancara peneliti dengan subjek F, H, A, dan ASR. Didapat pada dimensi ini subjek F, H, A, dan ASR. Mempunyai penanganan pada dirinya sendiri dengan melakukan kegiatan yang menghilangkan stress pada dirinya. Subjek F dengan cara memasak. Subjek 
$\mathrm{H}$ dengan cara berenang. Subjek A dengan cara mendekatkan diri dan subjek ASR dengan cara berjalan-jalan dan main game seharian.

Berdasarkan teori kambuh (relaps) pada dimensi keadaan emosi dan hasil wawancara peneliti dengan subjek F, H, A, dan ASR. Didapat pada dimensi ini subjek F, $\mathrm{H}$, A, dan ASR. Mempunyai keadaan emosi pada dirinya sendiri yang tidak terkontrol mereka kebanyakan merasakan ketakutan dan kecemasan dengan caranya masing-masing. Subjek F dari pemikirannya. Subjek H merasakan penolakan pada diri untuk memakai. Subjek A tidak ada penolakan dan subjek ASR ada penolakan tetapi tetap memakainya.

Berdasarkan teori kambuh (relaps) pada dimensi hasil yang diharapkan dan hasil wawancara peneliti dengan subjek F, H, A, dan ASR. Didapat pada dimensi ini subjek F, $\mathrm{H}$, A, dan ASR. Mempunyai harapan untuk sembuh dengan cara mengontrol diri, hidup sehat, kemauan keras, dan membuktikan dirinya bisa sembuh dari narkoba. Subjek F akan terus berusaha ketika gagal untuk sembuh dari narkoba. Subjek $\mathrm{H}$ melawan terus menerus untuk sembuh dari narkoba. Subjek A berusaha terus agar terbebas dari nakoba dan subjek ASR berusaha untuk sembuh total.

Di lihat dari faktor Eksternal yang memicu terjadinya relaps diantaranya yaitu: situasi yang menekan dan munculnya konflik interpersonal. Berdasarkan teori kambuh (relaps) pada dimensi situasi yang menekan dan munculnya konflik interpersonal dan hasil wawancara peneliti dengan subjek F, H, A, dan ASR. Didapati pada dimensi ini subjek F, H, A, dan ASR. Dengan cara dan sikap yang mereka lakukan untuk menyelesaikan permasalahannya. Subjek F dengan mengatasi permasalahannya sikap bodo amat. Subjek H mengatasinya dengan bersikap diam dan lebih berpikir positif. Subjek A mengatasinya dengan diam dan bersabar. Dan subjek ASR ketika mempunyai permasalahan dengan cara mengadapinya dan menjelaskan sesuai fakta.

\section{SIMPULAN}

Pelaksanaan konseling adiksi di bagi menjadi 3 tahapan jangka pendek, jangka menengah, dan jangka panjang. Metode layanan konseling adiksi FGD (Fokus Grup Diskusi), FSG (Familly Suppor Grup), dan pemberian materi kepada klien pasca rehabilitasi mengenai narkoba. Dampak konseling adiksi yang dirasakan oleh klien pasca rehabilitasi narkoba untuk mencegah kambuh (relaps) sendiri berdampak positif. Dari subjek F, H, A, dan ASR. F dan A memberikan dampak pada dirinya dari penyelesaian permasalahannya dan bersikap optimis untuk sembuh dari narkoba. $\mathrm{H}$ memberikan dampak pada dirinya terutama pada pemikiran menjadikan lebih berpikir positif dan optimis untuk sembuh dari narkoba. Dan ASR memberikan dampak pada dirinya dalam penguatan untuk sembuh dari narkoba dan optimis untuk sembuh dari narkoba. Cara mencegah kambuh (relaps) pada klien pasca rehabilitasi narkoba setelah mengikuti layanan konseling adiksi dengan subjek F, H, A, ASR. Niat untuk sembuh, menjauhkan diri dari lingkungan yang negatif, memilah teman yang baik, mempunyai kegiatan, dukungan keluarga dan berserah diri terhadap sang pencipta Allah SWT. 


\section{DAFTAR PUSTAKA}

Al-Sayyid al-Sabiq. (2009). Fiqih Sunnah Jilid 3 (Terjemahan: M.Ali Nursyidi). Bandung: PT. Al-Ma'arif.

Dwi, P. I. \& George, H. (n.d). Terapi Dengan Pendekatan Konsep Kongnitif Perilaku Untuk Mencegah Relapse pada pengguna Narkoba.

Hikmawati, F. (2012). Bimbingan dan Konseling (Cet. 3). Jakarta: Rajawali Press.

Hikmawati, F. (2010). Bimbingan dan Konseling. Jakarta: Rajawali Press.

Juliansyah, N. (2013). Metodologi Penelitian. Jakarta: Kencana.

Joewana, A. (2005). Gangguan Mental dan Perilaku Akibat Penggunaan Zat Psikoaktif. Jakarta: Penerbit Buku Kedokteran EGC.

Munthe, S. Endaria. (2017). Faktor-Faktor penyebab terjadinya Relapse pada Residen di medan plus lauch.

Nurihsan, A. J. (2006). Strategi Layanan Bimbingan dan Konseling. Bandung: Refika. Aditma.

Rahmawati, S. (2010). Relaps (Kambuh) pada Mantan Pengguna Nafza (Sebuah Studi Fenomenologi).

Setyawati. (2015). Buku seri Bahaya Narkoba Penyalahgunaan Narkoba (Jilid 2). Surakarta: PT. Tita Asih Jaya.

Setyawati. (2015). Buku seri Bahaya Narkoba Penyalahgunaan Narkoba (Jilid 3). Surakarta: PT. Tita Asih Jaya.

Shihab, Quraish. (2004) Tafsir Al-Misbah (Jilid 7). Bandung: Mizan.

Sugiyono. (2016). Metode Penelitian Pendidikan (Pendekatan Kuantitatif, Kualitatif, dan $R \& D)$. Bandung: Alfabeta.

Susanto, A. (2018). Bimbingan dan Konseling di Sekolah. Jakarta: Prenadamedia Group.

Zubaidah, S. (2011). Penyembuhan Korban Narkoba Melalui Terapi dan Rehabilitasi Terpadu. Medan: IAIN Press. 
254 | Beni \& Aryanie - Dampak Konseling Adiksi ... 